\title{
Introducing the Cardiovascular, metabolic and lipoprotein translation section of journal of translational medicine
}

\author{
Nehal N Mehta
}

\begin{abstract}
Introducing the Cardiovascular, metabolic and lipoprotein translation section of journal of translational medicine.
\end{abstract}

The Journal of Translational Medicine has focused on all areas of translational medicine derived from human experimentation to facilitate the communication between basic and clinical science. As the obesity, diabetes and cardiovascular disease epidemic continues to rise, especially with industrialization of developing countries [1], there is great need to focus on disseminating information between scientists and clinicians within this 'cardiometabolic arena'. Despite aggressive control of cardiovascular disease risk factors, residual risk [2] related to untreated or undiscovered pathways demonstrate the need for intensive research and communication in this field.

Indeed the thrust to discover novel pathways for therapeutics within the cardiometabolic arena is accelerating rapidly with the continued advent of technologies in genomics [3], biological assays [4] and collaborative science [5]. T1 translation [6] strives to connect basic science research to clinical research and has a strong foundation with a long history of wet lab experimentation. Basic scientists have a rich array of forums and journals in which they can disseminate their findings. Additionally, T2 translation revolves around the goal of bridging research into everyday clinical practice and health decision making, and includes guideline development, metaanalyses, and systematic reviews. A wide number of journals which are geared toward practitioners exist to facilitate communication within these fields. Finally, T3 includes dissemination and implementation research which includes policy-making and population-focused

Correspondence: nehal.mehta@nih.gov

Lab of Inflammation and Cardiometabolic Diseases, National Heart Lung and Blood Institute, Bethesda, MD, USA efforts, and many governmental agencies and publication forums are available for these efforts as well.

However, groups performing cardiometabolic and lipoprotein-based multi-disciplinary, translational research between the T1 and T2 phases often struggle to find an appropriate target journal to publish their findings because of the mixed content of basic and clinical research. This mismatch often delays publication of important findings due to the combination of multiple submissions to basic science and clinical journals. In order to increase the speed at which discoveries move from the lab into the clinic, ultimately improving the health of populations, fast and efficient communication is essential to keep up with these moving targets. Therefore, we here introduce the section of Cardiovascular, metabolic and lipoprotein translation within the Journal of Translational Medicine, which is devoted to the rapid publication of research papers within these fields.

This section aims to speed mechanistic understanding, development of novel diagnostics and potential therapeutic targets within cardiovascular, metabolic diseases and lipoprotein diseases. We are open to experiments involving cellular models, animal models, observational studies and clinical trials that are distinguished for their novelty in approach, design or indication, timeliness, and unique ability to translate laboratory concepts from the bench to the bedside. Highest priority will be given to those manuscripts which are specifically focused on cardiovascular, metabolic and lipid disorders which enrich understanding of disease mechanism, novel therapeutics and state-of-the-art scientific technique.

We invite your group to consider publishing your findings within this exciting new section which will be 
overseen by a talented group of Editorial Board members within cardiovascular medicine, lipoprotein biology, endocrinology, metabolism, animal biology, basic science and human genomics.

Received: 13 September 2012 Accepted: 13 September 2012

Published: 26 September 2012

\section{References}

1. Herman WH, Zimmet P: Type 2 diabetes: An epidemic requiring global attention and urgent action. Diabetes Care 2012, 35:943-944.

2. Mora S, Wenger NK, Demicco DA, Breazna A, Boekholdt SM, Arsenault BJ Deedwania P, Kastelein JJ, Waters DD: Determinants of residual risk in secondary prevention patients treated with high- versus low-dose statin therapy: The treating to new targets (tnt) study. Circulation 2012, 125:1979-1987.

3. Reilly MP, Li M, He J, Ferguson JF, Stylianou IM, Mehta NN, Burnett MS, Devaney JM, Knouff CW, Thompson JR, Horne BD, Stewart AF, Assimes TL, Wild PS, Allayee H, Nitschke PL, Patel RS, Martinelli N, Girelli D, Quyyumi AA, Anderson JL, Erdmann J, Hall AS, Schunkert H, Quertermous T, Blankenberg S, Hazen SL, Roberts R, Kathiresan S, Samani NJ, Epstein SE, Rader DJ: Identification of adamts7 as a novel locus for coronary atherosclerosis and association of abo with myocardial infarction in the presence of coronary atherosclerosis: two genome-wide association studies. Lancet 2011, 377:383-392.

4. Mehta NN, Li M, William D, Khera AV, Derohannessian S, Qu L, Ferguson JF, McLaughlin C, Shaikh LH, Shah R, Patel PN, Bradfield JP, He J, Stylianou IM, Hakonarson H, Rader DJ, Reilly MP: The novel atherosclerosis locus at 10q11 regulates plasma cxcl12 levels. Eur Heart J 2011, 32(8):963-971.

5. Saxena R, Elbers CC, Guo Y, Peter I, Gaunt TR, Mega JL, Lanktree MB, Tare A, Castillo BA, Li YR, Johnson T, Bruinenberg M, Gilbert-Diamond D,

Rajagopalan R, Voight BF, Balasubramanyam A, Barnard J, Bauer F, Baumert J, Bhangale T, Bohm BO, Braund PS, Burton PR, Chandrupatla HR, Clarke R, Cooper-DeHoff RM, Crook ED, Davey-Smith G, Day IN, de Boer A, de Groot MC, Drenos F, Ferguson J, Fox CS, Furlong CE, Gibson Q, Gieger C,

Gilhuiijs-Pederson LA, Glessner JT, Goel A, Gong Y, Grant SF, Grobbee DE, Hastie C, Humphries SE, Kim CE, Kivimaki M, Kleber M, Meisinger C, Kumari M, Langaee TY, Lawlor DA, Li M, Lobmeyer MT, van der Zee Maitland AH, Meijs MF, Molony CM, Morrow DA, Murugesan G, Musani SK, Nelson CP, Newhouse SJ, O'Connell JR, Padmanabhan S, Palmen J, Patel SR, Pepine CJ, Pettinger M, Price TS, Rafelt S, Ranchalis J, Rasheed A, Rosenthal E, Ruczinski I, Shah S, Shen $H$, Silbernagel G, Smith EN, Spijkerman AW, Stanton A, Steffes MW, Thorand B, Trip $M$, van der Harst $P$, van der DL A, van Iperen EP, van Setten J, van VlietOstaptchouk JV, Verweij N, Wolffenbuttel BH, Young T, Zafarmand MH, Zmuda JM, Boehnke M, Altshuler D, McCarthy M, Kao WH, Pankow JS, Cappola TP, Sever P, Poulter N, Caulfield M, Dominiczak A, Shields DC, Bhatt DL, Zhang L, Curtis SP, Danesh J, Casas JP, van der Schouw YT, Onland-Moret NC, Doevendans PA, Dorn GW, Farrall M 2nd, FitzGerald GA, Hamsten A, Hegele R, Hingorani AD, Hofker MH, Huggins GS, Illig T, Jarvik GP, Johnson JA, Klungel OH, Knowler WC, Koenig W, Marz W, Meigs JB, Melander O, Munroe PB, Mitchell BD, Bielinski SJ, Rader DJ, Reilly MP, Rich SS, Rotter JI, Saleheen D, Samani NJ, Schadt EE, Shuldiner AR, Silverstein R, Kottke-Marchant K, Talmud PJ, Watkins H, Asselbergs FW, de Bakker PI, McCaffery J, Wijmenga C, Sabatine MS, Wilson JG, Reiner A, Bowden DW, Hakonarson H, Siscovick DS, Keating BJ: Large-scale gene-centric meta-analysis across 39 studies identifies type 2 diabetes loci. Am J Hum Genet 2012, 90:410-425.

6. Sung NS, Crowley WF Jr, Genel M, Salber P, Sandy L, Sherwood LM, Johnson SB, Catanese V, Tilson H, Getz K, Larson EL, Scheinberg D, Reece EA, Slavkin H, Dobs A, Grebb J, Martinez RA, Korn A, Rimoin D: Central challenges facing the national clinical research enterprise. JAMA 2003, 289:1278-1287.

doi:10.1186/1479-5876-10-203

Cite this article as: Mehta: Introducing the Cardiovascular, metabolic and lipoprotein translation section of journal of translational medicine. Journal of Translational Medicine 2012 10:203.

\section{Submit your next manuscript to BioMed Central and take full advantage of:}

- Convenient online submission

- Thorough peer review

- No space constraints or color figure charges

- Immediate publication on acceptance

- Inclusion in PubMed, CAS, Scopus and Google Scholar

- Research which is freely available for redistribution

Submit your manuscript at www.biomedcentral.com/submit
C BioMed Central 